\title{
Disruptions, Decolonial Desire and Diaspora: A Provocation toward a Pacific Queer Worldmaking Scholarly Practice in Aotearoa-New Zealand
}

\author{
Seuta'afili Patrick Thomsen, Joshua Iosefo-Williams
}

\begin{abstract}
Pacific queer scholarship is underrepresented within Pacific research communities in Aotearoa-New Zealand. What does exist is either hypervisible or centres on narratives of oppression, both of which are archetypes that can deny the complexity of Pacific queer communities. As two queer Samoan scholars raised in the Aotearoa-New Zealand diasporic setting, we offer a provocation that tests the opportunities (and limits) queer theoretics provide for Pacific research. Through a combination of poetry, vignettes, and theory (queer and straight), as well as reflections, we intentionally and generatively transgress heteronormative, exclusionary and static boundaries that still exists within Pacific research in New Zealand.
\end{abstract}

\section{Introduction}

Queer theory, as an analytic, positions its multiple critiques in spaces where mismatches and inconsistencies exist within our socially constructed gender-sex and sexuality frameworks of normativity. ${ }^{1}$ These expectations, baked into the fabric of social and political order, binaristically and violently discipline bodies, intimacies, and desires in our quotidian existence. ${ }^{2}$ This paper is a provocation. As Pacific queer scholars, we call to other Pacific queer scholars and encourage Pacific thought leaders in Aotearoa-New Zealand to make space for us to explore queerness as an analytic: to consider its means of disruption as a generative complementary theoretic for Pacific scholarship and research in our country. ${ }^{3}$

Through combining disciplinary literature, storytelling, vignettes, and poetry we interrogate our positionality as children of the Samoan diaspora specifically, embedded in the whenua of our Māori whanaunga, raised in this settler-colony. ${ }^{4}$ This is an interrogation elevated in importance by takatāpui, fa' afafine and fakafifine scholars who have done incredibly important work in spotlighting the connection between colonisation and the suppression of Pacific queer worlds: critical work, seldom acknowledged in Pacific research communities. ${ }^{5}$

Having this connection well established in our research fields raises the question of the diasporic, transnationally embedded, Samoan, queer, Pacific experience in this context, as multiple generations of Pacific communities continue to develop in Aotearoa. ${ }^{6}$ Our experiences of being Pacific and queer, yet raised in a diasporic setting as transnationally displaced and located Samoans, we believe, informs in important, specific, unique, and disruptive ways how we interact with knowledge and divergent forms of research. We offer this short, dirty, gritty, reflective but ultimately optimistic essay to probe the specifics of this positionality, but also as a provocation to Pacific research communities to make space in our constellation of scholarship for the theoretics and challenges that Pacific queer scholars using queer theory can offer conversations around our Pacific scholarship and ways of knowing the world.

As Pacific social researchers, this is an important question. A core tenet of Pacific research in this country is accountability to our peoples through articulating transparently how our work within these colonial institutions of knowledge production serve the interests and advancement of our communities. ${ }^{7}$ As such, the position we take in this essay is that Pacific queer researchers in the Aotearoa-New Zealand context experience a duality of criticality, in seeking forms of 
queer liberation within a framework of decolonisation, whilst living within, around and between transnational diasporic realities that tie Samoan and Pacific queer intimacies, desires, and bodies to a colonial past and present. This complex reality we explore here is multifaceted, multilayered, intersectional, and subjected to violent historical ruptures, but is also uniquely transnational and diasporic.

The criticality of holding such conversations not only draws on our lived experiences as Pacific queer scholars, but also follows vital questions espoused by scholars in Indigenous and Native studies who have grappled with the question of whether congruence can be found between their disciplines and Western forms of queer theory. Notably, the question of whether there is space in their disciplines for a queer form of worldmaking that avoids erasure. ${ }^{8}$ Pacific studies - the foundational concepts of which are often coherent with and related to the work of Indigenous and Native studies scholars - is also due its own reckoning, a reckoning we take here to be generative, if constructively and generously embraced.

This essay barely scratches the surface of what is possible and is in no way a definitive roadmap of the direction we believe this research area can and should develop. It is our hope that these reflections may provoke other Pacific queer scholars to join in the task of suturing these ruptures together using queer theoretics as a disruptive, embedded in a Pacific Aotearoa-New Zealand diasporic context. It is from this position that we write: both Samoan children of South Auckland, raised in different generations, whose pathways into the academy have been unmistakably queer, without a current Pacific academic home to tie our work to. This paper is an articulated desire for a Pacific research futurity and space that is also, rather inclusively, sutured to our queer realities.

At its core, this is a queer paper. Threaded through theoretical links, we tell unsanitised stories and vignettes as a means to explore concepts that have been the terrain of many a queer and feminist scholar: undoing binaries and essentialisms, and exploring desires, forms of intimacy, and home as a way to express a Pacific queer worldmaking practice. ${ }^{9}$ Although this essay does contain a brief review of queer theory and its origins as a separatist movement from gay and lesbian studies as well as from empiricism, and into its own disruptive, postmodernist theoretical terrain, it is not meant to be exhaustive. We choose rather to explore select literature as links and possibilities as we build through the article. Ultimately, this queer (adjective) method is how we explore parallels in queer Pacific ways of knowing as we build conversations in response to the provocation of this special issue: what can a Pacific queer research agenda in Aotearoa-New Zealand look like, and what are the possibilities in this space for advancing the myriad communities we are all embedded within?

\section{A Queer Theory Genealogy in Brief}

As Samoan, Pacific scholars, we are quick to acknowledge that queer theory is foregrounded by a disruptive genealogy of its own and, despite its very Eurocentric roots, its origins have been undoubtedly fixed upon the theoretical task of disrupting normalcy. As Dave Halperin writes, "queer" was once commonly understood to mean "strange," "odd," "unusual," "abnormal," or "sick," and was routinely applied to lesbians and gay men as a term of abuse, but "queer" now intimates possibilities so complex and rarefied that entire volumes are devoted to spelling them out. ${ }^{10}$ In recounting its origins through Western universities and knowledge traditions, we also note that Professor Teresa de Lauretis coined the phrase "queer theory" as the title for a conference she held in 1990 at the University of California Santa Cruz as a deliberately disruptive act to innovate and reinvigorate debates around sex, gender, and sexuality. ${ }^{11}$ In particular, gay and lesbian studies were in the direct firing line, citing the

Journal of New Zealand Studies NS33 (2021), 94-109 https://doi.org/10.26686/jnzs.iNS33.7385 
uncomfortable fact that the discipline had been dominated by empiricist social scientists, limiting the theoretical potential of queer thinking to essentialist assumptions around identity. ${ }^{12}$

Since then, a plethora of queer theorists and literature have emerged, helping to create distance from gay and lesbian studies and queer theory as two distinctively yet inevitably intertwined and connected modes of research thinking and enquiry. ${ }^{13}$ Many scholars have taken up de Lauretis's provocation associated with gay and lesbian studies in particular, opening a wider space within it for reflections of a theoretical order, to introduce a problematic of multiple differences into what had tended to be a monolithic, homogenising discourse of (homo)sexual difference, and to offer a possible escape from the hegemony of white, male, middle-class models of analysis. ${ }^{14}$

Eve Sedgwick's foundational text Between Men, as precursor to de Lauretis's provocation, helped to map this terrain by drawing the homosocial back into the orbit of "desire," of the potentially erotic, as a way to hypothesise the potentiality in the continuum between homosocial and homosexual. ${ }^{15}$ Between Men revised what should have been obvious, but for so long not only went without saying but was treated as unspeakable: what is forbidden to heterosexual desire is first and foremost homosexual desire. In doing so, Sedgwick redefined heterosexuality as a fear of male homosexuality that motivates men to route their desire for one another through women. ${ }^{16}$ Her conclusion is that heterosexuality is not just a product of the relations between men and women; rather, it is also a consequence of, and a reaction to, relations between men.

Sedgwick's Epistemology of the Closet, first published in 1990, is another foundational text in queer studies, building on the theoretical ground established in Between Men. In it, Sedgwick makes many key advances for the field, pushing gay and lesbian studies beyond the essentialist-social-constructionist debate. ${ }^{17}$ Of key importance, this establishes the homosexual-heterosexual divide as one of the critical structuring forces in all modern Western identity and organisational frameworks. By establishing this symbiotic relationship between the two, Sedgwick's argument disrupts the "minoritizing" position in lesbian and gay politics that suggests same-sex relations and desire are only unique to and relevant to a small number in society. Rather, the fact that heterosexuality is a category that emerges after the discursive pathologising of homosexuality suggests that the focus should also be on making known and disrupting binaries, and problematising the societal ascribing of sexuality as well as gender from birth. In Epistemology of the Closet, Sedgwick poses the "closet" as the defining oppressive structure of gay existence, and in "coming out it positions and defines gayness, and queerness by extension, in opposition to heterosexuality. Living outside the closet can be fraught with danger but also celebratory, in emancipating repeated acts where gay identity can be performed and embodied. ${ }^{18}$

Judith Butler's Gender Trouble, which emerged at roughly the same moment as Epistemology of the Closet, homes in specifically on the performative aspect of gender. ${ }^{19}$ In Gender Trouble, Butler argued that gender is a repeated performance that has no essentialist foundation, meaning it is continually reproduced, thus is always open for subversion. Butler reorients our understanding of gender in our societies by proposing that it develops out of a "heterosexual matrix" that frames femininity as the desire for men while masculinity is framed as the desire for women. ${ }^{20}$ The heterosexual matrix of gender also makes it necessary for same-sex identification to be paired with cross-sex desire. As such, a taboo emerges where heterosexuality renunciates homosexuality, which prohibits straight people from mourning the homosexuality they must repudiate. ${ }^{21}$ In doing so, Butler reconceived heterosexuality as the 
melancholic mimicry of a lost but unmourned homosexuality; a heterosexual woman becomes the woman she cannot have, a heterosexual man seeks to embody the man he is barred from desiring. ${ }^{22}$

Since the early protagonists in queer theory staked their theoretical ground, the disruptions that queer theory offered to many scholars primarily located in the West have also resulted in anomalies of their own. Queer theory, the origins of which lay in making known and undermining the normalcy assigned to gender categories and heterosexuality, has been suspiciously and rapidly assimilated into normative disciplines, especially in the liberal arts. This has led to many queer scholars questioning: what is actually queer about queer theory? ${ }^{23}$ As queer theory emerged as a more capacious understanding of divergences in gender-sex and sexuality, incorporating notions of desire to overcome the essentialist modes of enquiry endemic to gay and lesbian studies at the time, this critique also tied itself to advances in feminist scholarship. This gave licence to many theoreticians to emphasise the theory above the queer, essentially allowing one to supersede the other. ${ }^{24}$ This means that queer theory was readily being applied to advance the practice of various academic fields by "queering" them. A critical task emerges, then, around the future and relevance of queer theory. Writing not long after the turn of the millennium, Halperin suggested that queer scholars needed to find ways of renewing its radical potential, and not by devising some new and more avant-garde theoretical formulation of it but, quite concretely, reinventing its capacity to startle, to surprise, and to help us think what has not yet been thought. ${ }^{25}$

\section{Queer Worldmaking and Queer Scholars of Color}

Many of the most interesting answers and possibilities to Halperin's challenge have emerged from non-white scholars. Kevin Duong, drawing on the work of Berlant and Warner, proposes queer worldmaking as a way forward. ${ }^{26}$ Duong advances the process of a queer making of a commons through claims for a common world that does not exist, that is technically unimaginable, but is nevertheless retained as a possibility by enacting the aspiration to live another way now. José Esteban Muñoz, the late great queer Latino scholar, writes similarly, rejecting the pragmatism of today's queer mainstream politics and craving for inclusion, choosing rather to pivot toward a queer utopia that embraces the radical, erotic and ordinary. ${ }^{27}$ Muñoz writes in a way that offers a type of queer futurity that is a queer worldmaking of its own.

Martin Manalansan, a queer scholar from the Philippines, reminds us of the uniqueness of experiences of queerness that exist outside of Western contexts. ${ }^{28}$ In their case, through the simultaneously enthralling and racially inflected experiences of Filipino global divas who engage in their own sense of queer worldmaking through a diasporic lens in contemporary New York. Central to Manalansan's work is the overlaid experience of queerness intertwined with diasporic challenges that embed desire within hierarchies of race, class, and transnational mobilities. Inevitably, these interwoven societal cleavages raise questions around the multiple cultural logics that inform sexuality and desire, as well as one's sense of gender-sex or sexual identity. For Pacific queer folk, the complex experience of a multilayered, transnational diasporic existence in New Zealand draws many congruencies with Manalansan's work. ${ }^{29}$

For Pacific queer scholars, the theoretical and empirical questions that arise from this entry point become clear. How does an exercise in queer worldmaking align itself with questions around Indigeneity and a decolonial, antiracist queer politic? Many Pacific and wider Indigenous scholars have articulated assertively that colonisation sought to eliminate all forms of queerness, or gender liminal, non-binary expressions, within Indigenous communities the 
world over. ${ }^{30}$ They have mapped out notions of homophobia, transphobia, and heterosexism as tied to the same marginalising processes that sought to colonise and eradicate Indigenous peoples, nations, and worlds. ${ }^{31}$ As such, the obvious task for Pacific queer scholars in a colonial context is not only to disrupt notions of heterosexism that threaten us with violence, but in doing so, we must also actively and knowingly disrupt simultaneously notions of coloniality as they continue to govern gender-sex and sexuality within the settler contexts in which we have pitched our diasporic tents.

\section{A Personal Reflection on Douching as Decolonial Praxis}

As a queer Pacific man, I physically cleanse my colon before having sex. Regularly and carefully, I douche deliberately, part of a queer ceremony and ritual that is a defiant physical act of decolonisation. I feel the mandatory yet strenuous process of waiting for the brown fluid released from my brown body to turn clear, mirroring the uncomfortable and confronting process of the washing out of colonial structures from one's being. Douching for the first time can be an embarrassing, horrific ordeal. It most certainly was for me. I recall a comment I came across online that claimed that gay sex is the only type of sex that people actually have to plan and prepare for. It wasn't until I explained to my straight friend what douching was and its necessity for my queer body to enjoy bodily pleasure that I realised that this presexual intercourse ceremony is not only exasperating but a niche experience shared only by the "brave." 32 Unlike for cis women, for whom anal sex is often seen as a risqué, optional way to diversify one's sex life, for queer men like me, this act is compulsory.

Filling the douche with warm water, lubricating the head as well as the anus, inserting the tip slowly, negotiating pain and discomfort, breathing deeply with each inch. Squeezing the water inside, feeling the warmth and body of water connect and cleanse then pulling the device out slowly releasing a gush of brown bodily fluid that reminds me of what I should and should not have eaten that day. In preparing for the ultimate expression of queer desire, in search of

climactic release we start with the most anticlimactic of all events, where during the process of watching faeces leave my body, I begin to question whether the sex is really worth the hassle.

\section{Impossible Desires and a Search for Home}

In Gayatri Gopinath's Impossible Desires, queer desire is articulated from a queer diasporic position that aims to decentre queer theory that is white, cis male, and Eurocentric, replacing it with a focus more on "Eastern" or further different cultural ways of understanding and reclaiming queerness. ${ }^{33}$ Gopinath and other queer scholars of colour offer us an analytic that acknowledges the Eurocentrism of much queer theory that emanates from the West. This commitment to decentring Euro-American expressions of queerness facilitates our confidence to articulate our own, Pacific ways.

As a queer Pacific man, I reflect on the possibilities of what Gopinath has marked out as impossible desires. Writing about queer desire from a Pacific perspective is just as uncomfortable as writing about douching. I have never written or dabbled in erotica or the intimacies of queer bodies; however, in reading Gopinath's work I am compelled by the notion that as a queer diasporic body experiencing bodily desire, there is some sort of resistance and reclamation of power that connects body, queerness, and Pacific-ness. This is not just limited to sexual intimacies; it extends to the nuanced intimacies within and between body, in and between queerness, Pacific-ness, and in and between vā. ${ }^{34}$ The intimacies and intricacies of being in a queer Pacific body, of family relationships, and of our multifaceted, perplexed concept of "home." 
The Pacific concept of vā is described by Iosefo and Iosefo as the third space of in-between that is all encompassing of the physical and relational world. ${ }^{35}$ The vā can manifest in over 37 different ways, such as the vā fealoaloa'i, the space of respect, and vā tapuia, identity and sacred space. ${ }^{36}$ The vā is used to describe not only the space that is physical but space that exists between people internally and externally through the fluid "in-between." ${ }^{37}$ As a queer Pacific body, my own identity constructed within the vā was not created in isolation, but was first formed in the intimacies of my mother's womb. ${ }^{38}$

Dear Mum,

It amazes me that before I was even brought into this world I was already a part of you.

Joined with you, by the umbilical cord, waiting in the warm chambers of you.

Held in incubation, protected by your flesh, moved by you, and swaying in your ocean.

A body-to-body connection, sharing soul, sharing breath, sharing nutrients, sharing life.

Cradled in your nest even before I would be born into this world, you held me, defended me, sheltered me, kept me safe, preparing me for nine months before I would come out.

So why was my closet any different?

This closet was far from you, it was not warm, or tender, like you.

It was cold, the walls slowly closing in, depression and confusion seeping through the walls and the only thing we shared was our space.

I always felt a strong connection to you, as if our brains were one, that our umbilical cord was never truly severed, as if we had mastered the art of telepathy, and I knew exactly what you were thinking because I felt it. Do you remember feeling it? ${ }^{39}$

As a Pacific queer body, the intimacies I share also live and breathe through the vā, the space that I have with my mother and by extension my family. I view my queerness and Pacific-ness within the wider cultural context of family, and my identity is strengthened through these relationships. In explaining the queer diasporic body, Gopinath discusses the concept of "home" and how colonial structures and pressures continue and are perpetuated first at home, and can make subjects feel displaced and "othered." 40 While many queer texts refer to home as a place to escape from or leave behind, queer migrants and those of the queer diaspora see home as a place of transformation where the concern is remaking the space of home from within, as opposed to running away from home.

Home was never somewhere for me to escape from, as this would mean leaving my family. Home, instead viewed as being my mother's womb, is about reclaiming my identity within my family, and restoring and reconnecting the umbilical cord. To simply romanticise this process and to say that I was accepted into my family for my queerness because of my diasporic identity is far from the truth. Reclaiming home and my umbilical cord has been a long, tedious, and difficult process that has taken years of reconciliation and decolonisation of worldviews that my family once viewed as being an integral fabric of our identity. One of the concepts put forward by Gopinath is that in being a queer diasporic body there is a reclamation of precolonial powers, and that violent colonial histories continue to resonate in the present day, making themselves felt through bodily desire: "it is also through the queer diasporic body that their legacies are imaginatively contested and transformed." 41 
As a queer Pacific body, I reclaim my precolonial Pacific history through my queer diasporic bodily desire. This history includes Pacific terms that identify and affirm queer bodies, terms such as leitī in Tonga, fa'afafine in Sāmoa, 'akava'ine or laelae in the Cook Islands, māhū in Hawaii, and raerae in Tahiti. ${ }^{42}$ I reclaim terms such as "tauatāne," which is normally used to describe homosexual acts between men, and restore its original meaning to "brave men" where the original translation means "war-husband" or "precious-man." 43 This intergenerational connection, this ancient lineage and sacred space shared between queer Pacific bodies today and our forefathers/mothers/parents/ancients before us is what I describe as the vā fetū: the space between stars. ${ }^{44}$ Through this definition of space we view the vā not only as space but space-time where the spaces between stars (vā fetū) are a metaphor giving queer Pacific bodies a place to exist in the next life without the colonial Christian narrative of a singular heaven. ${ }^{45}$ By using space between stars as a measurement, the degrees of separation are not by distance, but by time, meaning that through the vā fetū an intergenerational umbilical cord between my body and my ancient queer ancestors is made possible. Gopinath shares a similar sentiment, that to be a queer diasporic body you have an innate desire to return to the motherland. She draws from the work of Stuart Hall, stating that:

"The relation is where the experience of displacement gives rise to a certain imaginary plenitude, recreating the endless desire to return to 'lost origins,' to be one again with the mother, to go back to the beginning." If conventional diasporic discourse is marked by this backward glance, this "overwhelming nostalgia for lost origins, for 'times past," a queer diaspora mobilizes the questions of the past, memory, and nostalgia for radically different purposes. Rather than evoking an imaginary homeland frozen in an idyllic moment outside history, what is remembered through queer diasporic desire and the queer diasporic body is a past time and place riven with contradictions and the violence of multiple uprootings, displacements, and exiles. ${ }^{46}$

There is power in being. A power in being Pacific. A power in being queer. A power in being a child of the migrant dream, and a power in having queer desire. I would argue that as queer diasporic bodies, there is vā that exists within, between, and outside our own bodies, from the trembling of presexual intercourse rituals such as douching, in our umbilical cords that cultivate the intimacy and connection felt between us and our families, and in the possibilities of being a walking body that reclaims the land and identity taken from our ancient queer ancestors. Queer diasporic bodies are in constant motion; even when we venture to the stars in the afterlife, we return through the vā fetū through ritual, through connection, through a summoning of reclaimed terms, and through culture. Just as messy and necessary as the ceremonies we perform on ourselves as queer bodies, we must continue to decolonise; to do so is to claim our right to existence.

\section{Queer Reflection on Calls to Decolonise in the Academy}

I often have "queer" thoughts.

Ruminating quietly at the back of my mind as I chase another deadline governed by Gregorian time.

I hear your call to decolonise, it's lovingly gobbled up by an imaginary unitary Pacific public in Aotearoa. Your audience is captivated.

But I am not moved by your romantic, imagined recollections of precolonial times, for I have seen you produce the same colonial violence toward us you reject for your own.

Although the spirit of my ancestors' past guide my gut instincts;

tattooed onto my tongue through Sāmoan alagā'upu, it is a material dystopian reality in neoliberal settler hell that governs all my necessities. 
Tuck and Yang say to decolonise is to give land back, nothing else matters.

My spirit agrees. Land back. Everything else is a distraction.

But I am distracted.

Epeli, Teresia and many of our forebears say the ocean, our Moana, connects us, then why do I feel disconnection?

I see you mouth casually: that's a colonial way of thinking, too.

I waver in the face of such sureties.

What notions of home can we build in a land that is not ours?

Does it matter than I'm queer?

I often ask questions that no one wants to answer.

It's probably not polite to ask.

What is this Pacific excellence I am called to cultivate?

Decentring "Western ways of knowing," passionately espoused in lecture halls of overly priced university courses, consigning swathes of our youth to lifetimes of debt.

What am I doing here?

I have no answer, only more questions.

For Pacific scholars, the university and academy at large offer different urgencies that shape the opportunities we are likely to pursue, contrasting our mission to that of our Pākehā colleagues. ${ }^{47}$ Many of us believe that our work is to help decolonise curriculums, to disrupt the foundational whiteness that afflicts the academy, to make spaces safer for Pacific students. ${ }^{48}$ We take on the task of creating and holding space for those who will come after, whom we are called to train so that they can be better than us. ${ }^{49}$

I share these urgencies with my Pacific colleagues, but questions that arise for me are unavoidably shaped by my queerness, which places me on the outer of a group already shuffled to the edges of New Zealand society. This intersectional manifest is not an urgency that many of my Pacific colleagues have to share. There are already so few Pacific scholars in New Zealand; much of the intersectional work rightfully focuses on Pacific women. I am called to this banner and I enthusiastically work to support this cause.

It is in thinking about this troubling sense of invisibility that I find Kimberle Crenshaw's guidance most helpful and instructive. For Crenshaw, convergence points are where multiple forms of marginality intersect and become blind spots when attempts to redress inequities are single axis focused, effectively failing to illuminate that we actually exist. ${ }^{50}$ This intervention, designed to make legible the intersectional struggle of Black Women's experience in the United States, aids the anchoring of me as a simultaneously hypervisible and invisible Pacific queer scholar within a heterosexist Pacific academy. In many ways, I believe that my existence is taken-for-granted as purely marginalised as an entry point to our worthy resuscitation, and minoritised as part of a smaller subset of the wider community, despite being called to serve all Pacific communities. In Aotearoa-New Zealand, there is acknowledgement that we matter as Pacific people, and as queer people, but rarely do the two meet in the research foci of groups I am inevitably folded into.

It is unfortunate that this sort of erasure can risk a haphazard invoking of the dreaded "oppression Olympics," which I wholeheartedly reject here. ${ }^{51}$ It does, however, bear mentioning that in meetings and panels where I have experienced clear exclusion from Pacific men as a result of my queerness, I have also encountered on rare occasions, some Pacific women assertively pointing out that as a "man" I have privilege that they can never have. Rejected by both Pacific men and Pacific women, in some cases, leaves me in the middle with 
no home within a fledgling Pacific epistemological community. Consider also how even fewer Pacific queer women and non-binary assigned female at birth scholars exist in this space. The intersectional complications move beyond even the degrees of invisibility queer and gay men experience. The decision to underscore these complex layers of oppression is in no way meant as an accusation; rather, the point is intersectional, and one that relates to how an identity-based critique has limitations in this setting. By identifying these layers, as we target them, there should never be an intention to harden hierarchies of power as immutably socially constructed. To do so would be fatalistic and contradictory, falling victim to the same logic we wish to avoid. Rather, the real issue here lies with those who hold normative visions of the world. ${ }^{52}$ Normativity and the process of normalising essentialisms offers the greatest threat to all possibilities, not just queer worlds.

We as Pacific queer scholars, both of us called "emerging," and one the only openly queer Pacific scholar with a Pacific queer research programme at present in a New Zealand university, are both precariously positioned in relation to everyone in the Pacific community, not just men. This makes the need to build meaningful coalitions a critical action to gain allies and support for our existence. In many ways, we must attend to contested worldmaking practices and posited visions of justice to underwrite political solidarities and alliances. In other words, our actions must disrupt historical and social structures while we attend to the critical task of community building, lest we slip into yet another essentialism. ${ }^{53}$ This is an imperative for Pacific queer scholars, as "support" is tenuous when there are no investments within Pacific communities themselves in our continuation.

In Aotearoa-New Zealand, we as a queer Pacific community have been forced to live through public vilification by Pacific sportspeople, conservatives, and churches, whose dominance of Pacific communities has led to a false assumption that they lead and speak for all of us in the diaspora. ${ }^{54}$ This internal erasure is sanctioned by a Pākehā settler-colonial government that has demographic and economic investments in crafting us as a singular, essentialised group, ready to work. ${ }^{55}$ This narrative of conservative unsupportive Christian Pacific churches, we argue, is an essentialism that sustains political investments in othering us instrumentally as a way to map out a "progressive" mainstream New Zealand, sharply contrasted against our racialised and wrongly framed "unsophisticated" communities. This narrative continues to sustain racial hierarchies that rely on a type of condemnation of queer barbarism that is suspiciously located within our communities' religious institutions and rarely pointed to in non-Pacific settings. ${ }^{56}$ We who grew up in particular church settings in New Zealand know that the experience is far more complex than this framing. Divergences exist between denominations and family settings, and moments regularly exist where our inclusions are celebrated. This, however, is not a corrective committed to restoring those who have enacted violence upon us; instead, it commits our thinking to a complexity that allows multiple truths to exist at once.

Another truth is that violent exclusions are things we experience from certain groups and other churches here in New Zealand and in our homelands. Examples include the recent tragic murder of Tonga Leiti Association President "Poli," the murdering of Fijian trans women and the unethical reporting on fa' afafine death in Sāmoa; together, these speak to the multilayered, complicated and relentlessly precarious positions we occupy within our communities. ${ }^{57}$ Thus, in many ways, for Pacific queer folk like us, the collectivity of the label Pacific can be so all encompassing that not only can it be erasive, it can also be violent. In the diasporic setting this is an added complexity we face as we negotiate our Pacific and specific ethnic marginalities, whilst remaining positively queer. The need for meaningful coalitions and relationships becomes clear, precipitating a type of decolonial praxis for many of us that must begin with the 
critical need to develop and nurture relationships. As Phylesha Brown-Acton always highlights in her discussions around multifaceted Pacific queer realities, genealogies lead before anything else. ${ }^{58}$ Pacific worldviews are relational, and so too are Pacific queer worlds, alongside the possibility of a Pacific queer futurity bound up within these vā, these relationships, these practices of building, respecting and enhancing mana. ${ }^{59}$

It is here where the disruptive - and especially the agitative - elements of queer theory and its articulated praxis from white scholars and activists often reaches an instrumental limit in academic space. To decolonise must also mean a commitment to build, strengthen, and continue one's genealogies. It necessitates a commitment to queer worldmaking practices. A world that can celebrate the vā fetū, the spaces in-between. Where we can shape, remake, draw, and ultimately continue the genealogical lines between who we are and the ancestors we have and are to become.

\section{Concluding Discussion: Pacific Queer Worldmaking}

Queer worldmaking is about a type of futurity that is committed to a queer making of a commons. ${ }^{60}$ Duong suggests that it is through claims for a common world that does not currently exist, and which is technically unimaginable, that such a futurity is nevertheless retained as a possibility, enacting the aspiration to live another way now. This is a key lesson gleaned from many queer theorists through their work that celebrates the quotidian and the possibilities of a future that is tied to pasts we are not allowed to mourn publicly, yet somehow commit to in their continuation.

As such, this paper has offered queer thoughts that speak to this question of what a Pacific queer world could look like from academic perspectives. We suspect, however, that the answers are not likely to be found in the academy on their own, if at all. If a Pacific queer commons is to be established and somewhat vaguely distinguishable, it is likely that our artists and creatives will continue to provide the provocations, our performers will continue to disrupt spaces and entertain defiantly whilst serving looks, and our activists will continue to agitate in the face of immense hostilities. But these actions already exist in the here and now. What are we living today in our imaginations that seeks a reparative Pacific and queer future?

These deeply important questions are inextricably tied to chronopolitics and queering notions of chrononormativity. ${ }^{61} \mathrm{We}$ refer to chronopolitics here as a politics of time, which calls into question how concepts of time and history give meaning and legitimacy to political actors, groups, and ideas. This process of giving meaning and legitimacy is socially and culturally constructed through political and scholarly practices. Our notions of time are normatively governed by the colonial, but they are also heteronormative. ${ }^{62}$ As Jack Halberstram notes, queerness not only emerges in opposition to normative institutions such as marriage and heterosexist nuclear families but also accretes in queer temporalities and oppositional "life events" such as coming out, non-linear and creative life schedules, gender transitions, and generation-defining phenomena like the AIDS epidemic. ${ }^{63}$ Furthermore, as Michelle Tea notes, the queer life cycle diverges from heteronormative banality, meaning that the queer adult is forced to accept the political act of exclusion. In other words, to become a queer adult is to live a life wrought with incongruencies. ${ }^{64}$ Although marriage equality has now passed in New Zealand, queer couplings in this vein often seek to reproduce a type of family-making practice that is legibly normative, a practice that Lisa Duggan refers to as a politics of homonormativity. ${ }^{65}$ This is a type of queer practice which seeks not to disrupt the oppressive, patriarchal normalcy of the marriage institution, but rather chooses to embrace it and reproduce it, landing a fatal blow to the disruptive allure of queer politics. 
For Pacific scholars, these critical incisions from queer theory disrupt the omnipresent heteronormative nature of chronopolitics and align with our attempts to reclaim non-colonial forms of time. Our worldviews do not orbit around a type of clinical Gregorian timekeeping. Even within the current colonial configurations of time we are forced to live with, our worlds do not rely on linearity. Pacific worldviews rely rather on connections, rhythms, cycles, flows and energies that move backward and forward simultaneously, connecting all generations. ${ }^{66}$ Our reflections in this essay pay homage using a queer method to this complexity by recalibrating our words and reflections as a tribute to our genealogical connections to a diasporic home, accessed through our own gafa (genealogy), through our mothers and families, expressing a type of queer desire that disavows colonial constructs in time by washing it from our bodies and our minds.

As such, queer worldmaking for us as Pacific queer scholars, we believe, must be concerned with articulating a politics of genealogical indigeneity that embraces queer notions of time, space and relationships. In fact, our Pacific queer world is one in which we seek continuity through connections and relationalities with our Pacific cultures, languages, villages, towns, and families. A question that splinters here, then, relates to how the reclamation of queer worlds is inevitably tied up with the process of decolonisation. If our future queer worlds, both imagined and lived, are based on a type of genealogical connection and indigeneity, then we will have to move past the politically expedient idea that precolonial Pacific societies simply did not care about queerness or deviance. As enticing a notion and possibility as this may offer, as Jodi Byrd points out in the native studies and Indigenous studies space in North America, if we accept Indigenous worldviews and conceptualisations of gender capacious enough to account for queerness as a liberatory act, the end result is still erasure. In our case, what do we sacrifice in our queerness to be folded back into the normalcy of a decolonial future? In other words, what is queer about being a Pacific queer person in a cultural and knowledge framework that considers us normal?

However, in this productive tension - and others - we see value and potential for a queering of Pacific scholarship and politics in Aotearoa-New Zealand. This is because we, as all Pacific people, first and foremost represent a continuation in gafa that is inherently queer, as claiming it destabilises the normalcy/singular linearity of colonial politics, time, structures, and history. It does not make all Pacific people queer; rather, it supposes that our insistence on claiming this gafa is a queer act of resistance in the face of colonial violence, providing the opportunity to unlock queer worldmaking practices from a Pacific sensibility. Once we reach a definitional impasse, further discussions can be had as to how we bring these worlds into sense as our realities continue to diversify, diverge and grow within diasporic and mobile transnational communities.

An assertive disavowal of colonial structures allows queer desires to exist outside a political referent in the Pacific community context as one that is wrapped up in the act of decolonisation. This then gives us the opportunity to develop conversations around how we can articulate our own sense of queerness in a way that aligns with our own cultural context and worldviews beyond a framework of alterity and deficit, subjected to the Western gaze. This may appear to teeter on the edges of circularity and contradiction, but we believe that in many Pacific contexts to be queer is not to be queer with just other queer people; we live out our queerness with our families, friends, communities - conservative in many cases - held together through the tensions pulled by the threads of our shared genealogy. Thus, we argue that this reality does exist in a generative and admittedly opaque tension, offering many possibilities for advancing 
conversations on Pacific research based in Aotearoa-New Zealand. This necessitates Pacific research spaces being open to Pacific queer scholars, and to the theoretics our particular positionality present to Pacific research in our communities.

To close, we would like to offer a final comment. The provocation we offer is not a call for cisheteronormative Pacific scholars to drive Pacific queer scholarship; rather, it is a call to make space for Pacific queer scholars, acknowledging the generative uniqueness our scholarship can offer in developing new directions in New Zealand-based Pacific research. The decolonial research project for Pacific queer scholars is one in which our connections are developed, nurtured, cared for and enhanced, as the project of colonialism and ongoing settler-colonialism has been primarily concerned with severing our connections to our lands, to our peoples, and to families and wider communities. Reclaiming our roles as queer Pacific folk within our genealogies and birth families is an act of resistance and one that our scholarship must be encouraged to develop. This brings us into essential coalition with non-queer folk, but one where our words and positionalities still matters. We believe that this also brings many possibilities for a Pacific queer research agenda in Aotearoa-New Zealand and the spaces in the vā fetu for us to explore, as we undertake the urgent and fresh task of building a Pacific queer worldmaking scholarly practice.

\footnotetext{
${ }^{1}$ Patrick S. Thomsen, "Transnational Interest Convergence and Global Korea at the Edge of Race and Queer Experiences: A Talanoa with Gay Men in Seoul," Du Bois Review: Social Science Research on Race 17, no. 2 (November 16, 2020): 411-28, https://doi.org/10.1017/S1742058X20000247.

${ }^{2}$ José Esteban Muñoz, Disidentifications: Queers of Color and the Performance of Politics, Cultural Studies of the Americas, volume 2 (Minneapolis: University of Minnesota Press, 1999).

${ }^{3}$ Many people with divergent gender-sex and sexual identities use different terms; we use the term queer here in a purely scholarly sense and context, acknowledging that for some it is an identity framework they either embrace or reject. We also acknowledge that in the Pacific context, we have our own culturally specific terms to refer to gender-liminal and non-binary identities. Our use of the term queer is not meant to detract in any way from that complex reality. We use "Aotearoa-New Zealand" to denote moments of optimism and "New Zealand," singular, to denote when we are referring to the omnipresence of New Zealand the settler-colonial State.

${ }^{4}$ Throughout this paper, as co-authors we use "we" and "I" interchangeably. "We" is used to indicate that we both share a similar or the same experience; a shift to "I" denotes an individual experience expressed separately by a specific author, although which author has written which piece is not specified. This is a deliberate choice by the authors, as these unmarked shifts hold our separate experiences in productive tension with each other and position us in conversation with wider Pacific communities we are both tied to in different ways and contexts.

${ }^{5}$ Elizabeth Kerekere, "Part of the Whānau: The Emergence of Takatāpui Identity-He Whāriki Takatāpui” (PhD thesis, Victoria University of Wellington, 2017); Patrick Thomsen, “'Hobgoblin' Logic on Pacific Gay Rights Has Distinctly Western Roots," The Spinoff, 26 October 2016, https://thespinoff.co.nz/society/26-10-2016/hobogblin-logic-on-pacific-gay-rights-has-distinctlywestern-roots/; Dan Taulapapa McMullin, "Fa'afafine Notes: On Tagaloa, Jesus, and Nafanua," Amerasia Journal 37, no. 3 (1 January 2011): 114-31, https://doi.org/10.17953/amer.37.3.96h284334p363432; Phylesha Brown-Acton, "Hands and Feet: A Reflection on Polynesian Navigation-A Niue Fakafifine Community Practitioner Perspective in Aotearoa-New Zealand," Te Kaharoa 15, no. 1 (25 February, 2020), https://doi.org/10.24135/tekaharoa.v15i1.298; Dan Taulapapa McMullin, Shigeyuki Kihara, and Tressa Berman, "LeVasa: Dan Taulapapa McMullin and Shigeyuki Kihara in Conversation with Tressa Berman on Sea Changes, Transnationalism, Transgender and Cultural Translation," Pacific Arts 8 (2009): 40-51, https://www.jstor.org/stable/23412034.
} 
${ }^{6}$ For a review of the development of Pacific communities in Aotearoa-New Zealand, see Peggy Fairbairn-Dunlop, and Gabrielle Sisifo Makisi, eds., Making Our Place: Growing up PI in New Zealand (Palmerston North: Dunmore Press, 2003).

${ }^{7}$ For more information regarding Pacific research ethics, see Health Research Council of New Zealand, Pacific Health Research Guidelines, 2014 (2014), http://www.hrc.govt.nz/sites/default/files/Pacific\%20Health\%20Research\%20Guidelines\%202014.pd f; See also Patrick Thomsen and Phylesha Brown-Acton, "Manalagi Talanoa A Community-Centred Approach to Research on the Health and Wellbeing of Pacific Rainbow LGBTIQA+ MVPFAFF Communities in Aotearoa New Zealand," Pacific Health Dialog 21, no. 7 (22 June 2021): 465-71, https://doi.org/10.26635/phd.2021.117.

${ }^{8}$ See Jodi A. Byrd, "What's Normative Got to Do with It?: Toward Indigenous Queer Relationality." Social Text 38, no. 4 (145) (1 December 2020): 105-23. https://doi.org/10.1215/01642472-8680466; see also Billy-Ray Belcourt, "Can the Other of Native Studies Speak?," Decolonization: Indigeneity, Education and Society, 1 February 2016, https://decolonization.wordpress.com/2016/02/01/can-theother-of-native-studies-speak/.

${ }^{9}$ For an introduction to queer theory, especially in its early articulations see: Annamarie Jagose, Queer Theory: An Introduction (New York: New York University Press, 1996). From a queer of colour perspective, see Muñoz, Disidentifications.

${ }^{10}$ David M. Halperin, "The Normalization of Queer Theory," Journal of Homosexuality 45, no. 2-4 (23 September2003): 339, https://doi.org/10.1300/J082v45n02_17.

${ }^{11}$ Halperin, "The Normalization of Queer Theory."

${ }^{12}$ Teresa de Lauretis, "Queer Theory: Lesbian and Gay Sexualities. An Introduction," Differences: A Journal of Feminist Critical Studies 3, no. 2 (1991): iii-xviii.

${ }^{13}$ Halperin, "The Normalization of Queer Theory." 339-43.

${ }^{14}$ Halperin, "The Normalization of Queer Theory." 339-43.

${ }^{15}$ Eve Kosofsky Sedgwick, Eve Kosofsky. Between Men: English Literature and Male Homosocial Desire. , Gender and Culture. (New York: Columbia University Press, 1985).

${ }^{16}$ Halperin, "The Normalization of Queer Theory." 339-43.

${ }^{17}$ Eve Kosofsky Sedgwick, Epistemology of the Closet, updated edition with a new preface (Berkeley: University of California Press, 2008).

${ }^{18}$ Much of this summary comes from Mark Reschke, "Book Review: Epistemology of the Closet," Law and Inequality: A Journal of Theory and Practice 9, no. 3 (1991): 567, together with a rereading of Sedgwick's work for the purposes of this paper.

${ }^{19}$ Judith Butler, Gender Trouble: Feminism and the Subversion of Identity, Thinking Gender (New York: Routledge, 1990).

${ }^{20}$ Butler, Gender Trouble, 37-38.

${ }^{21}$ Butler, Gender Trouble, 48-49, 53.

${ }^{22}$ Sharon Marcus, "Queer Theory for Everyone: A Review Essay," Signs: Journal of Women in Culture and Society 31, no. 1 (1 September 2005): 191-218, https://doi.org/10.1086/432743.

${ }^{23}$ David L. Eng, Judith Halberstam, and Esteban José Muñoz, "What's Queer about Queer Studies Now?" Social Text 23, no. 3-4 (2005): 1-18.

${ }^{24}$ Sharon Marcus, "Queer Theory for Everyone: A Review Essay," Signs: Journal of Women in Culture and Society 31, no. 1 (1 September 2005): 191-218, https://doi.org/10.1086/432743.

${ }^{25}$ Halperin, "The Normalization of Queer Theory." 339-43.

${ }^{26}$ Kevin Duong, "What Does Queer Theory Teach Us about Intersectionality?" Politics and Gender 8, no. 3 (2012): 370-86, https://doi.org/10.1017/S1743923X12000360. This work draws from Lauren Berlant and Michael Warner, "Guest Column: What Does Queer Theory Teach Us about X?" PMLA 110, no. 3 (May 1995): 343-49, https://doi.org/10.1632/S003081290005937X.

${ }^{27}$ Muñoz, Disidentifications: Queers of Color and the Performance of Politics.

${ }^{28}$ Martin F. Manalansan, Global Divas: Filipino Gay Men in the Diaspora, Perverse Modernities (Durham: Duke University Press, 2003). 
${ }^{29}$ Patrick Thomsen, “There Are Ghosts in This Place: Growing up Sāmoan and Queer in 1990s South Auckland," Museum of New Zealand Te Papa Tongarewa, 1 October 2020,

https://www.tepapa.govt.nz/discover-collections/read-watch-play/history/lgbtqi-histories-aotearoanew-zealand/there-are-ghosts.

${ }^{30}$ For an introduction to this critique, see Qwo-Li Driskill, Queer Indigenous Studies: Critical Interventions in Theory, Politics, and Literature (Tuscon: University of Arizona, 2011). For an introduction tied to the Asian context, see Jennifer Ung Loh and J. Daniel Luther, "Queer" Asia: Decolonising and Reimagining Sexuality and Gender (London: Zed Books, 2019).

${ }^{31}$ Kerekere, "Part of the Whānau"; Patrick Thomsen, "In Defence of Pacific Sexual Minorities: Why Israel Folau Is No Hero," Pantograph Punch, 20 September 2017, https://pantographpunch.com//posts/why-israel-folau-is-no-hero; Patrick Thomsen, "We're Part of New Zealand's Pacific Story," E-Tangata, 30 May 2020, https://e-tangata.co.nz/reflections/were-part-of-newzealands-pacific-story/; Patrick Thomsen, "Israel Folau's Demise Is Also Partially Ours," E-Tangata, 13 April 2019, https://e-tangata.co.nz/comment-and-analysis/israel-folaus-demise-is-also-partiallyours/.

${ }^{32}$ Dan Taulapapa McMullin, and Yuki Kihara, Sämoan Queer Lives (Auckland: Little Island Press, 2018).

${ }^{33}$ Gayatri Gopinath, Impossible Desires: Queer Diasporas and South Asian Public Cultures (Durham, NC: Duke University Press, 2005), https://doi.org/10.1215/9780822386537.

${ }^{34}$ The vā in Sāmoan contexts refers to a sacred relational space that holds different people and relationships together. For an explanation, see Albert Wendt, "Tatauing the Post-colonial Body," Span 42-43 (1996): 15-29, http://www.nzepc.auckland.ac.nz/authors/wendt/tatauing.asp. The concept of vā in queer social research is still underdeveloped; one of the few to explore it in a queer studies/GLBT studies research project is Patrick S. Thomsen, in "Coming-Out in the Intersections: Examining Relationality in How Korean Gay Men in Seattle Navigate Church, Culture and Family through a Pacific Lens," Journal of Homosexuality 68, no. 6 (12 May 2021): 1015-36, https://doi.org/10.1080/00918369.2019.1695423.

${ }^{35}$ Homi K. Bhabha, The Location of Culture (London, New York: Routledge, 1994); in the Pacific context, see Fetaui Iosefo, "Who Is Eye? An Autoethnographic View on Higher Educational Spaces from a Pasifika Girl," in Global South Ethnographies, ed. elke emerald, Robert E. Rinehart, and Antonio Garcia (Rotterdam: SensePublishers, 2016), 199-208, https://doi.org/10.1007/978-94-6300494-7_16. Also see Fetaui Iosefo, “Third Spaces: Sites of Resistance in Higher Education?" Higher Education Research and Development 35, no. 1 (2 January 2016): 189-92, https://doi.org/10.1080/07294360.2016.1133273, and Bernida Webb-Binder, "Pacific Identity through Space and Time in Lily Laita's Va i Ta," in The Space Between: Negotiating Culture, Place, and Identity in the Pacific, ed. A. Marata Tamaira, occasional paper series 44 (Honolulu: Center for Pacific Islands Studies, School of Pacific and Asian Studies, University of Hawai'i at Mānoa, 2009), 25-34, http://scholarspace.manoa.hawaii.edu/handle/10125/14681.

${ }^{36}$ Jerodeen Fetaui Iosefo, "Moonwalking with the Pasifika Girl in the Mirror: An Autoethnography on Spaces in Higher Education" (master's thesis, University of Auckland, 2014),

http://hdl.handle.net/2292/32349; I'uogafa Tuagalu, "Heuristics of the Vā," AlterNative: An International Journal of Indigenous Peoples 4, no. 1 (2008): 107-26, https://doi.org/10.1177/117718010800400110.

${ }^{37}$ Iosefo, "Third Spaces."

${ }^{38}$ Fetaui Iosefo and Joshua Iosefo, "Hear, Here You're Naked Truth," Departures in Critical Qualitative Research 9, no. 2 (1 May 2020): 62-71, https://doi.org/10.1525/dcqr.2020.9.2.62.

${ }^{39}$ Iosefo and Iosefo "Hear, Here, You're Naked Truth," 66.

${ }^{40}$ Gopinath, Impossible Desires.

${ }^{41}$ Gopinath, Impossible Desires.

${ }^{42}$ Niko Besnier and Kalissa Alexeyeff, eds., Gender on the Edge: Transgender, Gay, and Other

Pacific Islanders (Honolulu: University of Hawai'i Press, 2014). 
${ }^{43}$ McMullin and Kihara, Sāmoan Queer Lives.

${ }^{44}$ Joshua Hio-Peaufa Jacob Iosefo-Williams, "If There Are No Doors in a Fale, Where Do We "Come Out' Of? Supernova-A Screenplay and Exploration of the Intergenerational Space Shared (In)Between Queer Pasifika Family Members" (master's thesis, Auckland University of Technology, 2021), https://openrepository.aut.ac.nz/handle/10292/14168.

${ }^{45}$ Webb-Binder, "Pacific Identity through Space and Time."

${ }^{46}$ Gopinath, Impossible Desires. She quotes from Stuart Hall, "Cultural Identity and Diaspora," in

Theorizing Diaspora, ed. Jana Evans Braziel and Anita Mannur (Malden, MA: Blackwell, 2003), 245.

${ }^{47}$ See Patrick Thomsen et al., "In Our Own Words: Pacific Early Career Academics (PECA) and Pacific Knowledges in Higher Education Pedagogical Praxis," Higher Education Research and Development 40, no. 1 (2 January 2021): 49-62, https://doi.org/10.1080/07294360.2020.1852188.

${ }^{48}$ Marcia Leenen-Young et al., "'Pillars of the Colonial Institution Are like a Knowledge Prison': The Significance of Decolonizing Knowledge and Pedagogical Practice for Pacific Early Career Academics in Higher Education," Teaching in Higher Education (26 May 2021): 1-16, https://doi.org/10.1080/13562517.2021.1928062; Joanna Kidman and Cherie Chu, "Scholar Outsiders in the Neoliberal University: Transgressive Academic Labour in the Whitestream," New Zealand Journal of Educational Studies 52, no. 1 (1 July 2017): 7-19, https://doi.org/10.1007/s40841-0170079-y; Patrick Saulmatino Thomsen et al., "Practising Pacific Pedagogies during New Zealand's Level Four Lockdown: Pacific Early Career Academics and COVID-19," Waikato Journal of Education 26 (5 July 2021): 149-61, https://doi.org/10.15663/wje.v26i1.754.

${ }^{49}$ I wish to acknowledge Alice Te Punga Somerville, who in a conversation via Twitter explained that the late great Tongan scholar Epeli Hau'ofa once explained to the late great i-Kiribati and Black scholar Teresia Teaiwa that as Pacific academics our job is to train students to become better than us. ${ }^{50}$ Kimberlé Crenshaw, "Demarginalizing the Intersection of Race and Sex: A Black Feminist Critique of Antidiscrimination Doctrine, Feminist Theory and Antiracist Policies," The University of Chicago Legal Forum 1 (1989): 139-67, http://www.bristol.ac.uk/media-

library/sites/law/documents/Demarginalizing\%20the\%20Intersection\%20of\%20Race\%20and\%20Sex $\% 20-\% 20 \mathrm{~A} \% 20 \mathrm{Black} \% 20 \mathrm{Feminist} \% 20 \mathrm{Critique}$.pdf.

${ }^{51}$ The first recorded use of the term "oppression Olympics" came in a 1993 conversation between Elizabeth "Betita" Martinez and Angela Davis, where Martinez urges us to move past the futility of engaging in a hierarchizing of suffering and to instead harness that rage to build coalition among the marginalised. A transcript of the conversation can be found at https://culturalstudies.ucsc.edu/inscriptions/volume-7/angela-y-davis-elizabeth-martinez/. See also Elizabeth Sutherland Martínez, De Colores Means All of Us: Latina Views for a Multi-Colored Century (Cambridge, MA: South End Press, 1998).

${ }^{52}$ Duong, "What Does Queer Theory Teach Us about Intersectionality?"

${ }^{53}$ Duong, "What Does Queer Theory Teach Us about Intersectionality?"

${ }^{54}$ Thomsen, "Israel Folau's Demise Is Also Partially Ours."

${ }^{55}$ Sean Mallon, Kolokesa Uafā Māhina-Tuai, and Damon Ieremia Salesa, eds., Tangata o Le Moana: New Zealand and the People of the Pacific (Wellington: Te Papa Press, 2012).

${ }^{56}$ Jasbir Puar's articulation of homonationalism is helpful here, where Puar tracks how the heteronormative state has many investments in the continued portrayal of barbaric Muslim States that treat their homosexuals badly as an excuse to intervene and spread liberal politics. The instructive we take here is that the New Zealand settler-colonial State has much invested in the continual framing of our communities as conservative as a way to assert its progressive and liberating legitimacy. For a deeper reading of homonationalism, see Jasbir K. Puar, Terrorist Assemblages: Homonationalism in Queer Times, second edition (Durham, NC: Duke University Press, 2017).

${ }^{57}$ Lily Wakefield, "Tributes Pour in for 'Beloved, Selfless' LGBT+ Activist Found Murdered on Beach,” PinkNews, 3 May 2021, https://www.pinknews.co.uk/2021/05/03/tonga-lgbt-activistpolynesia-murder-polikalepo-kefu/; Liam Fox, "Murdered on International Day against Transphobia: Fears Fiji Killing Is a Hate Crime," ABC News, 23 July 2018,

https://amp.abc.net.au/article/10026188?pfmredir=sm; Laura Walters, "Sāmoan Reporting on Trans Woman's Death 'Disgusting,' 'Degrading.'” Stuff, 20 June 2016, 
https://www.stuff.co.nz/world/south-pacific/81256086/Sāmoan-reporting-on-trans-womans-deathdisgusting-degrading.

${ }^{58}$ Thomsen and Brown-Acton, "Manalagi Talanoa."

${ }^{59}$ Upolu Luma Va'ai and Gwaiaweng Kiki, eds., Relational Hermeneutics: Decolonising the Mindset and the Pacific Itulagi (Suva, Fiji: The University of the South Pacific and the Pacific Theological College, 2017).

${ }^{60}$ Duong, "What Does Queer Theory Teach Us about Intersectionality?"

${ }^{61}$ Renate Lorenz, Not Now! Now! Chronopolitics, Art and Research, Publication Series of the Academy of Fine Arts Vienna, volume 15 (Berlin: Sternberg Press, 2014).

https://doi.org/10.21937/9783956791086.

${ }^{62}$ An obvious counterexample being the Maramataka in Aotearoa. For more discussion of noncolonial notions of time, see Pauline Harris et al., "A Review of Māori Astronomy in Aotearoa-New Zealand," Journal of Astronomical History and Heritage 16, no. 3 (2013): 325-36.

${ }^{63}$ Judith Halberstam, In a Queer Time and Place: Transgender Bodies, Subcultural Lives, Sexual Cultures (New York: New York University Press, 2005).

${ }^{64}$ Michelle Tea, Black Wave, First Feminist Press edition (New York: Feminist Press at the City University of New York, 2016).

${ }^{65}$ Lisa Duggan, "The New Homonormativity: The Sexual Politics of Neoliberalism," in Materializing Democracy (Durham, NC: Duke University Press, 2002), 175-94.

${ }^{66}$ Multiple authors have spoken about the differences in Pacific ways of understanding time; for a contemporary take, see Katarina Tuinamuana and Joanne Yoo, "Wayfinding and Decolonising Time: Talanoa, Activism, and Critical Autoethnography," in Wayfinding and Critical Autoethnography, ed. Fetaui Iosefo, Stacy Holman Jones, and Anne Harris (Milton: Routledge, 2020) 53-68. 